\title{
TTR
}

Traduction, terminologie, re?daction

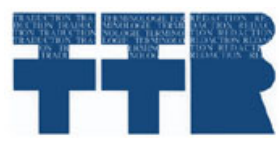

\section{Writing Between Cultures}

\section{Barbara Godard}

Volume 10, numéro 1, 1er semestre 1997

Langues, traduction et post-colonialisme

Languages, Translation and Post-Colonialism

URI : https://id.erudit.org/iderudit/037280ar

DOI : https://doi.org/10.7202/037280ar

Aller au sommaire du numéro

\section{Éditeur(s)}

Association canadienne de traductologie

ISSN

0835-8443 (imprimé)

1708-2188 (numérique)

Découvrir la revue

Citer cet article

Godard, B. (1997). Writing Between Cultures. TTR, 10(1), 53-99.

https://doi.org/10.7202/037280ar

\section{Résumé de l'article}

Écrire entre les cultures - Cet essai examine le trafic des langues ou interférences systématiques, les tropes de la traduction par lesquels se constitue le réseau du système littéraire canadien. Deux moments sont ici considérés. Le premier, lorsque les littératures canadiennes se constituent comme l'Autre de l'Europe par la traduction verticale de concepts canadiens dans les langues classiques ainsi que par l'effacement des traductions horizontales entre les langues amérindiennes, ainsi que l'on peut l'observer dans les écrits de la colonisation et particulièrement dans ceux de Marie de l'Incarnation. Le second concerne la période contemporaine où le théâtre des cultures amérindiennes, celui de Daniel David Moses en particulier, remet en scène le trope de la non-traduction afin d'exposer la violence rhétorique de l'impérialisme et offre comme option un modèle de traduction horizontal entre les langues amérindiennes. La performance comme répétition dans la différence où la ré-écriture s'offre comme un autre mode de traduction caractérisé par une théorie du langage en tant qu'événement et non mimesis.
Tous droits réservés (C) TTR: traduction, terminologie, rédaction — Les auteurs, 1997 cost protégé par la loi sur le droit d'auteur. L'utilisation des services d'Érudit (y compris la reproduction) est assujettie à sa politique d'utilisation que vous pouvez consulter en ligne.

https://apropos.erudit.org/fr/usagers/politique-dutilisation/ 


\section{Writing Between Cultures}

\section{Barbara Godard}

[...] learning all these words by heart, as well as memorizing all the verb-forms was like having stones rolling around in my head. The whole thing seemed to be humanly impossible. (Marie de l'Incarnation, Relations [1654], 1985, p. 137)

White Girl: "School's a strange place....Your throat gets sore....You cough a lot too. I used even to cough blood. And they won't let you talk. They try to make you talk like they do. It's like stones in your mouth". (Daniel David Moses, Almighty Voice and his Wife, 1992a, pp. 19-20)

A nation is not defeated until the hearts of its women are on the ground. (Cheyenne proverb, epigraph to Almighty Voice and his Wife)

These epigraphs, from the texts to be analyzed, highlight the toil and spoil of translation. Through them, I want to examine systematic interferences between languages in Canada at two different moments in the wake of imperialism. During the period of first contact between Europeans and Amerindians, as exemplified in the seventeenth century writings of Mere Marie de l'Incarnation, Canadian concepts are translated vertically into European vernaculars and produced as Europe's other in a systematic erasure of horizontal translation among Amerindian languages that effects cultural and political hegemony. Turning in the second instance to the contemporary period, I shall examine the theatre of cultures of First Nations playwright Daniel David Moses who restages the trope of translation to expose therein the rhetorical violence of imperialism in a 
counter-hegemonic move. Whereas in the first moment, the bilingual Amerindian translating is figured as potential traitor, as 'lying thieving Indian', in the second, such duplicity is the power of Trickster, a culture hero who transforms the world.

I am more concerned here with non-translation than with translation 'proper', that is with a refusal to translate cultural or linguistic difference which produces divergent political effects in the two texts. The selection of language in a multilinguistic milieu is always a politically charged process of constituting what Gramsci calls a "normative grammar". "An act of cultural-national policy" such choices enact relations of ruling as they contribute to "the formation and enlargement of the ruling class" and establish relations "between the ruling groups and the national-popular mass" and so organize the "cultural hegemony" (1984, pp. 146-7). Language change as counter-hegemony develops through struggle with other models and historical phases working as forces of resistance to normative grammar. The "national language", as Gramsci notes, "cannot be anything but 'comparative"', cannot be imagined "outside the framework of other languages" (1984, p. 146). It is this performativity of translation I wish to analyze through an examination of some of the tropes of translation which constitute the conditions of possibility, the field of the sayable, ordering the movement between languages and cultures wherein the Canadian literature institution is produced. A country in translation necessitates a consideration of literature not in terms of identity but of relationality with a consequent attention to asymmetries between languages as these order relations of ruling.

The absence of a single national language, and consequently of a homogeneous literary system, is a topos of writing in Canada as

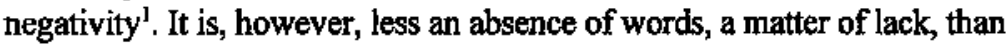
of excess, the difficulty of choosing among many words, I would suggest, that is a dilemma for the Canadian in an instance of "national heteroglossia" (Bakhtin, 1981 p. 295). If the boundary is the "hottest" site

\footnotetext{
1The lack of "haunting ghosts" lamented by Earle Birney in "Can.Lit." functions, paradoxically, as an identificatory fiction for Robert Kroetsch: Canadian writing manifests "resistance to a speakable name" $(1975$, p. 41$)$.
} 
of semiotizing processes where meaning-making occurs, as Lotman argues (1990, p. 136), where the distinction a culture makes of an ordered 'us' produces its particular type of disordered 'them' and such disturbances lead to the creation of a new cultural "semiosphere" (1990, p. 142), this entails a concept of semiotic activity in a cultural milieu as more than binary alterity. A boundary both separates and unites in relation to an outside and is, consequently, polylingual (pp. 136-7). Moreover, the space it encloses is transected by boundaries at different levels forming variously continuous or discontinuous spaces, possibly even some combination of open and fragmentally closed spaces. The boundary then is a point of constant exchange of signs producing cultural value.

Within the Canadian context, under official bilingualism, there has been a tendency to conceptualize linguistic and cultural relations in binary terms. Canada's policy of official "multiculturalism" encourages First Nations peoples and immigrants to retain their cultures, though not their languages which remain unofficial ${ }^{2}$. Multiculturalism, as culture without language(s) and authority, or voices reconciliable in one voice, figures an end of translation in a fiction of unanimity. Against this, I want to argue, Canadian literature discourse has developed within contradiction, between cultures, between languages. Contradiction is embedded in linguistic signs in their centrifugal potential or differently oriented accents of diverse speech communities, multiaccentuality which the ruling social formation strives to make uniaccentual. Critics' calls for a hybridized "national" language, "Anglo-Ojibwa" and "Franco-huronne," in the mode of indigenization of romantic nationalism in the nineteenth century, have given way to the creation of syncretic languages by polyglot writers mingling Chinese with English and Hindi'. Such contacts and interferences among languages, indeed the internal dynamism or dialectical aspect of the Canadian literature polysystem within itself, may

2 The terms of reference of the Royal Commission on Bilingualism and Biculturalism (1967-72) which first framed the issues of cultural and linguistic diversity established a clear hierarchy between "the two founding races" (English and French) and "other ethnic groups" (Report I xxi).

${ }^{3}$ Jamilia Ismail is such a trilingual writer. For more detailed analysis see my essays, "The Oral Tradition and National Literatures" and "The Discourse of the Other: Canadian Literature and the Question of Ethnicity." 
be traced through the boundary play of translation. During periods of cultural change, translation is significant in reorienting signs within multivalent accents, extending their vitality and development. In contemporary Canada, as in Renaissance Europe, translation is a mode of expansion or creation of knowledge through a proliferation of versions from different horizons of cultural perception.

\section{A Cultural Turn}

While currently there is a turn to more pragmatic policy analysis in Cultural Studies, discursive analysis continues to scrutinize rhetorical topoi and discern the ideological stakes of utterances. Such a metaphorics productively foregrounds the interpretive fictions or social logics of translation. A fluid activity, translation is conceptualized diversely in various 'national' languages and in a variety of tropes at different historical moments. A historicized pragmatics is crucial for understanding the differences between the translation theories of Marie de l'Incarnation and Daniel David Moses, I would contend. If the connotations of metaphorical and hermeneutic activities from the Latin and Greek terms of translatio and metapherein persist in present day understandings of "translation" as a transfer of concepts, they are enriched by other connotations ${ }^{4}$. Mère Marie de l'Incarnation gives the activity of transmission an expanded meaning of enrapture, I would suggest. Normative English language translation practice of textual equivalence is

4 Translatare refers to the displacement of people as well as to the physical transportation of objects and to the transfer of legal jurisdiction as well as of ideas : it might also connote being carried away in transport - enraptured - as well as taking possession of something. "Translation" which emerged in English in Mediaeval and neo-Classical texts connoted the circulation of translinguistic meaning conceived as separate from the medium of language in which it was expressed. Traduction emerged in sixteenth-century France from the Italian with a different semantic field meaning to lead across, to transform, or to bring before justice. Developing at a moment when translation becomes an object of discourse in rhetorical modes, not in the mode of conceptual leaming, the French translator is understood to be transferring texts from one well-demarcated language to another. Translation here implies the adaptation and acclimatization of the foreign in what is a secondary and inferior activity. This contrasts with the English "translation," which means the circulation of signifieds beyond all reference to either the near or the foreign in some ineffable transcendence. 
only one possible fiction, however. ${ }^{5}$. The Anishinaabe term for translation, aanikohtamowin, combines a prefix for "link" with a stem for "story", to imply that translation makes a connection by telling a story about a word ${ }^{6}$. Explicitly postulating translation as creation not imitation, this emphasis on textuality contrasts significantly with English's focus on semantics or French's concern with thetorical form. Such storying, I would suggest, informs Daniel David Moses's understanding of linguistic and cultural contact. So, translation develops a narrative that places a word within a social action. Each of these different articulations of translation activity frames specific understandings of the modalities of linguistic and cultural interference, establishing normative modes of contact, delimiting acceptable forms of relations and strategies of textual manipulation, and configuring speech genres. These relations produce certain hierarchies among signifiers, inscribing relations of power which may make the translator's turn a conversion or a reversion. Although the range of possible versions a translator may make is considerable, I shall concentrate on these stances to examine two different scenes of the

${ }^{5}$ Consider also the German übersetzung, "to set beside," which underlines the intertranslatability of languages as an interactive and reciprocal game between self and other, or the Hindi anuvad, connoting "the word sitting beside you" and "the word in dispute," establishing translation as contradictorily linking similarities and confronting differences.

${ }^{6}$ There are some eleven dialects in Anishinaabemowin (Ojibwe) which is spoken primarily in Ontario and to the south of the Great Lakes. One of seven Central Algonkian languages, contemporary Anishinaabemowin forms a distinctive subgroup evolved from Proto-Algonkian spoken about 3,000 years ago. Linguistic variation falls into two primary groups, northem (including Algonquin and Severn Ojibwe) and southern (including Chippewa, Eastern Ojibwe, Odawa and Saulteaux). Between the two are a number of definable subdialects. The Nipissing dialect to the east combines northem and southern features (Valentine, 1995, pp. 20-23). This term for translation was given by a speaker of the Severn dialect. A nineteenth-century dictionary gives "ahnekuhnootuhbeega" for "translate" and "ahnekuhnóotahga" for "interpret." The suffix "beega" means writing. "Story" is transcribed as "enáhjemowin" (Wilson, 1874). A lexicon drawing heavily on the Odawa dialect of Wikwemikong renders "interpret" as "aanikkanoottamaake" which combines the suffix "aanikko" (to join or tie together) with a suffix "akke" (to work with or make). Story or narrative is "tipaacimowin" (Piggott and Grafstein, 1983). Within this range of variants, the emphasis is on the active manipulation or work of bringing two languages into contact. 
passage between languages at different moments in the history of translation in the Canadas where the languages interacting are positioned within different axes of power; the one a scene of instruction, the other a scene of insurrection.

In the last decade, translation theory has taken a "cultural turn" (Bassnett and Lefevere 1990). The insight of Bakhtin into the heteroglossia as well as the addressivity of language conceptualizes sign systems as neither unified nor transcendent but meaning-making within vectors of power ${ }^{7}$. Languages are chains of potential relations among signifiers saturated with the play of social forces at a particular historical moment in a socially specific environment that orders the actualization of their connections. The translational utterance does not so much establish a "match" between languages as follow a particular trajectory toward the outsidedness of another language. Languages are always imbricated in relations of superiority or inferiority, asymmetrical relations which are agonistic and stratifying ${ }^{8}$. The word of certain speech communities is "authoritative," and taken for a general norm. There are languages and literatures of major and minor diffusion within global or even 'national' marketplaces. Within such a model of the ideological interrelation of languages, translation, or the rewriting of a text in a different conceptual horizon, is understood as one of a range of processes of 'manipulation' within certain vectors. The concept of difference - of contradiction or syncretism - even of the différend (incommensurability) and différance (indeterminacy) - displace dogmas of fidelity as concepts of translation activity. In the complex multi-directional movement of living on, translation may enlarge or constrain a text's authority.

Translation traffics in power. In the double movement of interanimation that is translation, languages, subjectivities, are ex-changed, relativized. Such "dialogism" points to the incompleteness of

"See my essay "Bakhtin and the Cultural Turn in Translation Studies" forthcoming in the Canadian Review of Comparative Literatures.

8 "Language is not a neutral medium" easily made "private property", for it is "overpopulated" with the languages of others, languages to which it responds or which it anticipates. "Expropriating it, forcing it to submit to one's own intentions and accents, is a difficult and complicated process" (Bakhtin, 1981, p. 294). 
all languages, to the absence of any homogenizing master language, not to posit the transcendence of the need to translate in some theological moment of signification or 'pure language' but, on the contrary, to insist on the dynamic interaction and contamination of languages in the continuous movement of transformation in the making and unmaking of hierarchies. There is nonetheless a difference in the effect of such commerce in languages depending on where one is positioned within the axes of power, and on the direction of the transfer - downwards, upwards or horizontally - along the hierarchy, whether one "translates" the self into the perspective of the other or translates the other into the language of the sovereign subject, or meditates on the difficulties of passage. The alienation of the self in power through recognition of oneself as a kind of foreigner in respect to a mastery one may yet attain differs from translation of the less powerful other who is transported into the self-same to be alienated from the self. The colonizing potentials of the latter constitute the "poetics of imperialism" (Cheyfitz, 1991, p. 115) wherein the other is transposed into the master code of empire in an act of con/version, as I shall term this 'turning', within a scene of instruction. An imperial politics of language in the Canadas in the work of Mère Marie de l'Incarnation" makes claims to understand "les Sauvages", refusing to

${ }^{9}$ Marie Guyart, bom in 1599 in Tours, grew up in a baker's family. Upon her marriage at seventeen to Claude Martin, a silkmaker, she left aside the vain reading of her youth to concentrate on books of piety and the psalms. Widowed at nineteen and with a year-old son, Claude, Marie helped run the transportation business of her sister and brother-in-law for a decade during which her spiritual life - mystical experience, mental prayer, works of charity, bodily mortification - became increasingly fervent. In January 1631 , she left her son to the protection of God and the Virgin and entered the Ursuline convent at Tours. The Ursuline order was bound by the rule of strict enclosure under the directives of the Council of Trent. Guided by her Jesuit confessor who interpreted her 1633 vision of walking with a laywoman in a silent mountainous land as a vision of Canada and filled with zeal for converting the "savages" inspired by reading the Relations of the Jesuits, Marie got the convent praying for the needy souls across the ocean. She also began writing to Père Le Jeune, Jesuit missionary in New France, who wanted some female religious to teach the Huron women. However, her dream of missionary work there became a possibility only when Madeleine de La Peltrie, a wealthy noblewoman also a widow, became interested in joining her and financed the journey as well as a house and church for the Ursulines in Quebec. They set sail from Dieppe with two other Ursuline nuns on May 4 1639. Marie's 
acknowledge its own powerlessness in the necessity for, and the inadequacy of, its cultural translation : the 'Savages' are understood as always-already European, superior Europeans, in fact, since they appear more zealous (submissive) in their devotion - easy converts.

The extent to which it is mistranslation and that the Amerindians can take up the language of Europeans without being confined to its limited meanings is what is at stake in the complex performance of "ghost" in Daniel David Moses's play. A focus on a "phono-semantic series" of signifiers (de Campos, 1982, p. 185), rather than on meaning that follows logic in its move from word to word by established connections, disturbs 'transparency' and 'transcendency' as strategies of colonial discursivity. Challenging the conventional hierarchies of 'major' and 'minor' literatures by granting precedence to the role of the translator or interpreter over the author and exploring the space in-between texts to write in what has been written out - the raced or gendered conditions of its transposition, the 'middle passage' or transportation between points of contact, the tropes of turning, the activity of cutting - this is translation practice which makes visible the cultural work of translation, its ethico-political effects. Such modalities of turning are concerned with horizontal relations between texts and languages as well as vertical relations of imposition, ones I shall characterize as creative re/versions staged in Almighty Voice and His Wife as scenes of negotiation ranging from armed insurrection to parodic resurrection. Translation studies converge here with cultural studies in an examination of the internexus of power, knowledge and subjectivity, concerns that animate my analysis of strategies of non-translation in 'Canadian' literatures at the height of and in the wake of the imperial moment.

son eventually became a Benedictine monk. At his request, she wrote a spiritual autobiography detailing her mystic visions, "La Relation de 1654 ", which, despite her instructions not to do so, he published along with her voluminous correspondence five years after her death in 1672. Marie de l'Incarnation wrote no systematic ethnographic description of the Amerindians, as did the Jesuits. In the last decade of her life, she began to write in the Amerindian languages composing catechisms, prayers, dictionaries and, in Algonkian, a work of theology, a "Sacred History", something she had not dared to do in French. These works have subsequently been lost. 


\section{Con/version}

"At the heart of every imperial fiction [...] there is a fiction of translation," asserts Eric Cheyfitz (1991, p. 15). In the Canadas, this is a story of a founding violence, a captivity narrative with many variants as French and Amerindians confined each other in forcible immersion. Jean Delisle begins his history of translation in Canada with the sentence : "Interpretation was the first profession practiced in Canada after the arrival of the Europeans" (1987, p. 33 emphasis added). That translation took place between different indigenous languages before their arrival is overlooked. He also neglects the violence of this professional debut in that the first translators were inducted into this profession by force aboriginal peoples abducted and transported to Europe ${ }^{10}$. Contact with

${ }^{10}$ Taignoagny and Domagaga, sons of Donnaconna, chief of Quebec, were kidnapped by Cartier on his first voyage in 1534 and returned to Quebec in 1535 when he kidnapped their father. Cartier, himself an interpreter of Portuguese in the port of St. Malo, taught French to the aboriginals, leaming only a few words of their language himself. His lexicon was completed with the help of Donnaconna. On his third voyage, he planned to send young men to live with aboriginals, but the immersion project ended after two days when the aboriginals conspired against the French. Captivity figures importantly in the apprenticeship of translators in the exploration phases of the colony. In the seventeenth century, Champlain sent young men to live with the Hurons, Algonquins and even the enemy Iroquois. They were subject to torture and other trials : when they withstood, proving their strength and courage, they were adopted into the tribes, as was the case with such celebrated "truchements" as Etienne Brulé, Guillaume Couture, Jean-Paul and Thomas Godefroy. Their knowledge of indigenous languages enabled them to profit from the fur trade. For this, they needed to become "masters of eloquence and persuasion," Delisle notes $(1975$, p. 29), because the English trading centres were closer than the French. The aboriginals had respect for the "esprit" of those who spoke their language, considering those who did not as less than human. This produced competition with the missionaries : the "coureur de bois" were reluctant to share their linguistic knowledge with the priests. There were also political differences : they became 'indianized' while the priests sought to Frenchify the Natives. Consequently, the priests began to make dictionaries so as to teach each other. For more analysis of these early interpreters see Jean Delisle, "Les interprêts sous le régime français" (1975). For an Amerindian perspective on multilingualism see Métis historian Olive Dickason $(1992$, p. 79$)$. 
North America was produced in translation both literally (in the narratives of contact edited by Hakluyt which promoted settlement of the Americas) and figuratively : the 'new world' came into being in a troping, overwritten by the 'old' whose perceptions framed its inhabitants under the universalizing figure 'Indian,' as a resource for exploitation and an object for conversion. Metaphor or translation - a carrying across as transportation and/or transference - has been the "very motor" of the "perceptual apparatus" of colonization (Cheyfitz, 1991, p. 109).

The dream of absolute power of the discoverer/conqueror is founded in an unacknowledged contradiction. The silence of the 'Indians' of North America, proliferated in the literature of exploration in the figure of the 'Indian' who speaks no language and the 'Indian' who speaks 'our' language (guides or "native informants") is, in fact, symptomatic of a different problem : the failure to recognize the figure "Indians speak a language and it is different from ours" (Cheyfitz, 1991, p. 109). 'We' do not understand this language and so its speakers appear silent or invisible to 'us'. This may also occur in its converse : 'we' all speak the 'same' language and 'we' all revere the 'same' object whereby 'we' come to cohere as subject. In effect, this is a figure of non-translation for what it presents as a problem in intercultural communication turns out to be a problem in intracultural competence, a problem with metaphor. A contradiction within one language between the "natural" and the "figurative" is projected outward as two incommensurate languages (Cheyfitz, 1991, pp. 121-2). A failure at dialogue is figured as a genetic inability of the other : the inferiority of aboriginal languages, their 'barbarity', becomes the imperial alibi for (rhetorical) domination. Two metaphorical machines encounter each other but only one is understood as rhetoric or art : the other is perceived as transparent or 'natural'. The translation of the 'inferior' by the 'superior' is simultaneously impossible, because of this qualitative discrepancy understood as intellectual deficiency, and inevitable, because of the same discrepancy understood as power differential (Cheyfitz, 1991, p. 122). The Amerindian is thus perceived to speak both gibberish (speaking with stones in her throat) and with a 'natural' eloquence in a language taught to him/her by Europeans. Aboriginal oral utterances as varied as oratory and prayer are (re)ordered within European rhetorical forms. Clashes between Amerindians and European power necessitate the production of written texts within European formal conventions as, for example, in the many letters of 
petition from First Nations peoples to government officials filed in the colonial archives (Petrone, 1983). Translation moves here to obliterate difference, to eliminate the need for transiation, to bring about its own end. The dilemma after Babel will be overcome when everyone understands 'our' language.

A myth of a 'common' language is central to the imperializing and civilizing project which equates speaking well with being human. Not to do so is to be a 'savage'. To speak well is to master a language, that is, to speak the language of the metropolis. Incoherency is translated into 'coherent' speech which 'makes sense' within what is so constituted as a 'universal' language, a 'colonizing' language. Translation of the 'other' into the codes of the empire entails a mission of conversion, most explicitly one of translation as instruction in the language and culture of the master. The connection of learning a language and mastery in the transfer of culture from one people to another transferred the Roman imperium, a model of an empire with Latin as a universal language, to maintain the (imperial) idea of a universal rather than national character ${ }^{11}$. A version of the mediaeval theory of translatio imperii et studii, suggests Eric Cheyfitz, this offered a theory of history as the cyclical replacement of one empire by another that was simultaneously a theory of rhetoric and one of translation. The transmission of knowledge (studii) was co-terminous with a geographical transfer connected to a transferral of power. While in France this later involved adapting knowledge to the language of the addressee and justified writing in the vernacular (Lusignan, 1988, p. 313), in the Canadian context, the Amerindian languages were refigured as Latin in a universalizing move that conceptualized the cultural transfer of empire as pan-European Renaissance or Catholic return to Apostolic fervour.

The translatio was both a theory of figurative language and a theory of the transmission of power in that it proposed a monologic theory of translation from and into (infraduction and supraduction) the hierarchically 'superior' languages of Europe. At its centre is a 'primal

${ }^{11}$ This was explicit in the development of the Carolingian Empire when Alcuin followed the details of the opening scene of De Inventione in a letter to Charlemagne in response to requests for the rules of rhetoric so that the emperor might rule properly (Cheyfitz, 1991, pp. 112-3). 
scene' in which an orator by his eloquence 'civilizes' a 'savage'. This "imperial commonplace" is the narrative of the orator as first settler or colonizer, bringing humanity and civility to 'wild savages' or 'wild lands', found in Cicero's De Inventione and De Oratore, texts used for centuries in the teaching of rhetoric or eloquent speaking (Cheyfitz, 1991, pp. 113-4) ${ }^{12}$. I shall turn to such a scene of instruction in the work of Mère Marie de l'Incarnation, a Canadian example in which Amerindian girls are taught to identify against themselves with the gospel's "poor in spirit" in order to gain greater power through transformation into French-speaking Catholics. This translation of the aboriginals into the terms of empire ironically writes them out of the empire as silent Other, eliminating the specificity of their cultures and languages and of the act of translation itself in the supraduction by conflation of Amerindian languages with Latin, universal language.

First, though, I want to talk about another kind of non-translation that fails to recognize the Amerindians' cultural difference while paradoxically writing that difference out(side). This variant of the failure to acknowledge that aboriginals have cultures and languages which are complete and autonomous, so that horizontal translation between Amerindian languages might figure in the relations of exploration and settlement, or that a dialogic countertransference might occur in the passage between European and aboriginal languages whereby the European would be transformed in the activity of translating, propagates the myth of the "empty continent" which enables the transfer (translation) of 'Indian' land into 'Canadian' property. In this case, within the context of English attempts to settle Newfoundland ${ }^{13}$, the 'Indians' are not overwhelmed by the eloquence of a European speaker, for there are no

\footnotetext{
${ }^{12}$ This topos still informs such nineteenth-century Quebec texts as the celebrated roman du terroir, Jean Rivard, where oratory and improvement of soil and habitans are the making of a hero as political ruler.

${ }^{13}$ On June 24 1997, Newfoundland celebrated the 500th anniversary of the landing of John Cabot (Giovanni Caboto) to claim the land for England.
} 
'Indians' visible ${ }^{14}$. They have been written out of the landscape entirely. The 'new world' is figured as incomplete, in need of the completion or settlement of the 'old'. The land is first translated into British property in an imperial project framed in Latin, that universal language of Renaissance humanism, in which the Hungarian scholar, Stephen Parmenius, bard of Sir Gilbert Humphrey's expedition, wrote to his Oxford friend, Richard Hakluyt ${ }^{15}$. Oscillating between documentary inventory, manipulating the figure of analogy to produce the "effect of the real" and naturalize the 'new world' for civilizing prospects, and prayer for favours from British patrons, Parmenius's letter produces a subject of the enunciation wherein the spoken subject is figured as powerless in comparison to the addressee. The threat of subjection is reduced by mastery of Latin rhetoric, language of eloquence and (self)-control. In the "absence of any people", "Newfoundland" functions as a screen of vacancy, in a relation between Europeans through which the subject differentiates himself as universal and powerful, filling the void with representations as imitations ${ }^{16}$.

14 This policy is different from that of the French who took Beothuks back to France to train them as interpreters before 1508 (1975, Delisle, p. 6). In the late sixteenth century, a French sailor observed that the Amerindians in the Straits of Belle-lsle traded in French, English, Gascony and Basque (1975, Delisle, p. 23-4).

${ }^{15}$ Parmenius was among those who died on that fatal expedition of 1583, but an epic poem he wrote of the settlement project and his letter to Hakluyt, both in Latin, survive as the first texts written in (British) North America. The letter, translated by Hakluyt, was published in his compilation of "explorer's" relations (Principall Nowigations 1589) of which it is, despite its brevity, rhetorically exemplary.

${ }^{16}$ Pamenius's text also sets in play the problem of translation within Renaissance Europe in the desacralization of languages and the emergence of vernaculars as state languages and, consequently, of national(ist) discourses. Becoming national is paradoxically for a language to become colonial and colonizing; colonial in differentiating itself from the universal language Latin, colonizing in representing itself mimetically as universal. Parmenius's letter appears in print in the English translation of Hakluyt, ardent promoter of England's colonizing projects. In his translation, Hakluyt amended his dead friend's text to remove lines where Parmenius had reported negatively on the coldness of the climate because of icebergs in May. Such textual manipulation in translation is in keeping with 
In the French relations of exploration and settlement greater aftention is given to both Amerindian languages and to translation. Jacques Cartier acknowledged the need for interpretation, albeit with a violent capture. To the Relation of his voyages are appended glossaries of Iroquoian terms limited, though, to elementary phrases of numbers, food, basic questions. Moreover, Cartier's description of the coasts of the Maritime provinces and of the St. Lawrence River is mediated by not one but two modes of perception, a marking of distinctions as well as a search for equivalences. He notes that the peoples he encountered "appellent ung hachot en leur langue cochy et ung cousteau bacan. Nous nomames ladite baye la baye de Chaleur" ([1545], 1986, p. 113). This is not an equal traffic in languages as the balanced rhetorical structure of the sentences would convey, but the prelude to a narrative of tricks and captures, where the reported calculation and feints of the Amerindians are met with ambushes and abductions by Cartier. Indeed, the pursuit of similarities dominates : this act of naming in a European language, follows a passage of description under the sign of equivalences ('we' are all Europeans) of the quality of the wheat and rye growing at this site, description positioned between two sentences predicting the ease of converting these aboriginals ${ }^{17}$. This opinion is formed after initial contact with aboriginals who have readily accepted axes, patemosters and other goods and given away everything they had in exchange until "they had nothing but their naked bodies" ([1580], 1975, p. 18). Such a perception of Amerindian submission to European persuasiveness stands in unmarked opposition to the observation a week later that "Ilz sont larrons à merveilles de tout ce qu'ilz peuvent desrober" ([1545], 1986, p. 116). Who is more credulous, it is difficult to discern. Reading between the lines, this contradiction manifests a cultural clash over concepts of property where a gift economy of hunter-gatherer culture confronts the private ownership of proto-capitalism and neither recognizes the other as a 'system'. Between

Hakluyt's literal use of translation in the strong sense of transfero and metaphero, to transport or carry something from one place to another, in a passage that is potentially enrapturing, "captivating" its reader.

17 "Nous congneumes que se sont gens qui seroint fassilles ì convertir... Je estime mielx que aultrement que les gense seroint facilles à convertir à notre saincte foy" ([1545], 1986, p. 113 emphasis added), quoted approvingly by Hakluyt in Discourse of Western Planting (1975, p. 4). 
these two sentences, Amerindians' dancing and speech-making ("harangue" [1545], 1986, p. 116) are noted uncomprehendingly by the European chronicler ${ }^{18}$, while the aboriginals' astonishment ("estonnez" [1545], 1986, p. 117) at the inside of Cartier's ships is emphasized as a sign of Donnaconna's good will ${ }^{19}$.

Relations between French and aboriginals are repeatedly constituted in this mode of misprision, the eye reading similarity, the ear distinguishing difference. The failure to attend to the silent cultural signs ordering modes of address, produces translation as metaphor, translation as violence. The authoritative certainty of the narrator in reporting these gestures as transparent in face of the incomprehensibility and hence untranslatability of the speech is nothing short of the marvellous. The European elides signs of resistance, that is, of difference : invisible, cultural incommensurability is thus transcended ${ }^{20}$. Cartier's "sauvages" are

${ }^{18}$ A frequent comment in Cartier's Relations is "Par default de langue ne pensames avoyr congnoissance".

${ }^{19}$ This rapture is read by the French as a sign that Donnaconna - wearing his bearskin, "haranging," and seeming ("comme s'il eust voullu dire que toute la terre estoit à luy" [1545], 1986, p. 116) to protest the planting of a cross in the name of the King of France - "qu'ilz ne habbatroyent ladite crois en nous faisant plusieurs harengues que n'entendions" ([1545], 1986, p. 117, emphasis added). Florio's translation - "woulde not remove the Cross we had set up" ([1580], 1975, p. 23) - leaves out the last phrase which records French inability to understand indigenous spoken languages, seemingly a matter less significant to the English.

${ }^{20}$ The Amerindians excel in the double play of illusion, staging a performance of sorcery in which they imitate Christian rhetoric and ritual in the name of "Cudouagny" to wam Cartier against travelling to Hochelaga. Cartier considers the refusal of Taignoagny and his brother to accompany him up river, as they had purportedly promised in France, to be "treason" and "trickery" ("Lors aperseumes que ledit Taigoagny ne valloit rien et qu'il ne songeoit que trahison tant pour ce que pour aultres tours que luy avyons veu faire" 1986, p. 143), but the miming of Christian ritual is related neutrally, without comment on its evident parody ("Et commança ledit Taignoagny à dire et proferer par troys fois 'Jesus Jesus Jesus' levant les yeulx vers le ciel et puys Dornagaya commança à dire 'Jesus Maria Jacques Cartier' regardant le ciel comme l'aultre" (1986, p. 145). How could Hakluyt, reading of this passage have interpreted the aboriginals as "easily converted"? 
"gense" ("people"), potential Europeans, in need of moulding or developing under a firm hand. We read aboriginal oratory as silence through Cartier's narrative rhetoric. What figures in his account is the venerable topos of traduttore traditore, the translator as traitor, here confounded with that topos of imperialism, the 'lying thieving Indian', suffering the pollution of bilingualism, of being between cultures as "crippled two-tongues" (Maracle, 1988, p. 109) ${ }^{21}$.

It is the persuasive "technology of eloquence" (Cheyfitz, 1991. p. 34) - thetorical power enhanced by the representational machinery of writing, a "literall advantage" (Purchase I, p. 486) - in the service of religious conversion, that figures prominently in the figure of translatio in the work of Mère Marie de l'Incarnation. Instruction is as effective a modality of figuring the Amerindians out of power as their elimination from topographical description by Parmenius or their capture by Cartier. The figure of instruction involves a paradox of translation as non-translation, the learning of Amerindian languages in order to bring the aboriginals to a recognition of the universal power of Latin, of Catholicism as transcendent Truth, through the sacred writings of christianity. Against the dangers of the forked tongue that would produce lies and errors in translation on the part of "native informants", is positioned the power of Christian ritual and rhetoric to guard against "delusion" (de l'Incarnation 1967, p. 76).

Containment is critical in Mère Marie de l'Incarnation's figuration of translation, but her's is a chosen captivity, the confinement of the cloister. This enclosure symbolizes 'civilized' femininity which she seeks to impose on the Amerindian girls sent to be educated in the Ursuline convent at Quebec. Aboriginal women had the freedom of the forest and "canote comme des hommes" ([1681], 1971, p. 829). More disturbing to the Jesuits was their sexual freedom unregulated by the

21 Significantly, French interpreters or "coureur de bois" received similar nicknames : Jean Nicolet was known as Achurra ("homme deux fois") for his linguistic skills while François Marguerie went by the name "homme double" (Delisle, 1975 , p. 52 , p. 61). This ready acceptance by the aboriginals earned them suspicion from the priests. When Etienne Brule and Nicolas Marsolet helped the English occupiers of Quebec in 1629, they were considered traitors by the civil authorities as well (Delisle, 1975, p. 39). 
concept of 'sin' (Anderson, 1991, p. 86). Realizing the impossibility of their goal should they not 'civilize' the aboriginal women, the Jesuits brought nuns to New France. Attracted by the enlarged possibilities for her own spiritual and administrative activity in the forests of Quebec where the apostolic authority of cloistered nuns received full recognition - indeed, the pioneer nuns were called "Amazones du Grand Dieu" Marie de l'Incarnation nonetheless sought to circumscribe her aboriginal pupils within the rules of discipline and surveillance of the cloister, instructing them through the Catholic rite of examination of consciousness in practices of psychological control to separate them from the negative (barbarous) influences of the forest. This is characteristic of the split subjectivity produced in feminist discourses with their contradictory values of enlightenment, emancipation or autonomy and of feminine difference as passivity and dependence. Marie's scrupulous exactitude in following the rule of the cloister, despite its ultimate hampering of her avowed vocation to win souls, places her discourse more heavily on the scales of feminine submission.

Her Correspondance oscillates between these contradictory pulls of assertion and subjection punctuating her portraits of aboriginal women, some noted for their heroic exploits in freeing themselves from Iroquois captivity and making their way back to Montreal or Quebec on their own ([1681], 1971, p. 329), others praised for their docility and submission to the nuns (p. 72). So, too, Marie de I'Incarnation destabilizes her own authority as knowing subject, minimizing her skill in learning Algonkian, Montagnais, Huron and Iroquois languages by attributing it all to divine inspiration ${ }^{22}$. Learning them, she wrote was "humanly impossible". So, she continues: "I spoke lovingly to our Lord about it, and he came to my aid to such a degree that in a short time I had a very great facility in the language so that the activity of my interior life was neither hindered nor interrupted" ([1654], 1985, p. 127). By effacing herself to become God's instrument, she will make possible the perfect translation of the Word. Meaning transcends the material modalities of communication : apparent disparities are absorbed into a vaster unity. Her letters are mediated by

${ }^{22}$ She compiled an Iroquois dictionary, a French-Algonkian dictionary, an Algonkian-French dictionary and a catechism in Huron, all of which have been lost, making analysis of her translation practice impossible. 
these two modes of perception, a marking of differences, of error and delusion, that transforms itself into a web of equivalences, of truth and illumination. The fall into the wildemess, into languages, serves as testimony to a providential mission to New France and as evidence of the particular grace bestowed on her as the devoted handmaiden of the Lord. This is, moreover, a particularly skillful rhetorical device for soliciting help for the project of New France.

The power of Providence manifests itself in rhetorical eloquence, as Mère Marie de l'Incamation records it : "Le R. Père le Jeune qui est le principal ouvrier qui a cultivé cette vigne, continue à y faire des merveilles. Il prêche le peuple tous les jours et lui fait faire tout ce qu'il veut : Car il est connu de toutes ces nations, et il passe en leur esprit pour un homme miraculeux" ([1681], 1971, p. 94 emphasis added). The transformative results of his preaching are evident in their effects, as Mère Marie observes upon her arrival in New France in September 1639 : the Christian God is "praised in four different tongues [Montagnais, Algonquin, Huron, French]" by aboriginal preachers which she reads as prophesy of her future, teaching girls of this "barbarous country" the way to heaven $\left(1967\right.$, p. 69) ${ }^{23}$. Certainly, this promise of the easy conversion of the aboriginals makes Mère Marie forget the perils of the ocean crossing where they had almost capsized, catastrophe forestalled by divine intervention. Commencing her voluminous Correspondance with these providential signs, Mère Marie establishes the rhetorical form of her relation, a litany of examples of God's benevolence. An insuperable difficulty is introduced as prelude to a demonstration of divine power, the lesson of the felix culpa or happy fall. This scene represents the universality of Catholicism, for the diversity of languages masks a singularity of meaning : "Nous sommes tous ici pour un même dessein" ([1681], 1971, p. 88). Christian eloquence holds out the promise of a single, pure language, a miraculous speaking in tongues where there is

23 "Car entendre louer la Majesté en quatre langues différentes : voir baptiser quantité de Sauvages : entendre les Sauvages mêmes prêcher la loy de Jésus-Christ à leurs compatriotes, et leur apprendre à bénir et à aimer notre Dieu; les voir rendre grâces au ciel de nous avoir envoyées dans leur paìs barbare pour instruire leurs filles, et leur apprendre le chemin du ciel; tout cela, dis-je, n'est-il pas capable de nous faire oublier nos croix et nos fatigues, fussent-elles mille fois plus grandes quelles n'ont été?" ([1681], 1971, p. 88) 
mutual comprehension and unanimity of belief - a common desire - that transcends and redeems the fall into Babel. Translation undertaken in the ethnocentric aim of conversion produces a vision of salvation - for Mère Marie at least.

This goal of sense-for-sense equivalence is based on a theory of textual transfer grounded in the onto-theological discourse of the one true "Word" and its many distortions, formulated in classical metaphysics and Biblical hermeneutics, and regulating the translation practice of the early Church Fathers working on the Vulgate (Robinson, 1991, p. 55). The theory postulates a hierarchized dualism with everyone - except God and his Logos or 'true meaning' at the top - an instrument of the level above and an instrumentalizer of the level below. Through divine inspiration, the Biblical translator will become invisible, an instrument of God, and make possible the perfect translation of 'Meaning', perfection being measured in the extent to which a translation supersedes the original. Such 'originality' is achievable only through slavish imitation which valorizes divine authorship and erases all traces of textual mediation. Applied to non-Biblical texts, this theory refuses to acknowledge conflictual relations between cultures and texts, assuming that translation occurs only between "identically-placed systems" (Bassnett, 1993, p. 146).

Christian eloquence thus contains the threat of translation, the duplicity and lying of those who speak many languages and distort the one true Word with their accents. Skill in the French language, as well as knowledge of the Catholic catechism, limit the threat of bordercrossing with its attendant risks of impurity by imposing a rigid hierarchy. Not only does this make the aboriginal pupils tractable but it enables the nuns to carry out their surveillance more effectively, as in Mère Marie's account of Marie Amiskouevan, a model of docile devotion, whose bilingualism is testimony to the persuasiveness of the French missionaries :

It ne se peut rien voir de plus souple ni de plus innocent; ni encore de plus candide, car nous ne l'avons surprise une seule fois dans le mensonge, qui est une grande vertu dans les Sauvages... Cette fille nous a beaucoup aidé dans l'étude de la langue, parce qu'elle parle bien François. Enfin cette fille gagne les coeurs de tout le monde par sa grande douceur et par ces belles qualitez" ([1681], 1971, p. 95 emphasis added). 
Submissiveness is the significant quality for verifying the reliability of her translation for it is a sign of her perfect mastery of the cultural rhetoric of European translation practices. Taking up the role of subservient handmaid positions her within her 'proper' role in the instrumental hierarchy, assuring the fidelity and transcendence of target language version in a movement of supraduction for the circulation of Meaning beyond all language. Marie's fidelity is corroborated in Les Relations des Jésuites where, following her marriage it is reported, "she gave proofs of a faith strong and animated by love," repelling the advances of several young pagans who were courting her, and reacting strongly to the ministrations of a traditional Shaman ("Iongleurs", [1640-1641], 1959, $\mathrm{XX}, \mathrm{pp} .128-9)$ to her sick brother. These proofs are gestures, tears and smiles - more secular than sacred signs - interpreted as rejection of aboriginal religious practices by the priest who presupposes cultural universals ${ }^{24}$.

This woman enters into the colonial archive with proper names (Marie-Magdeleine) ${ }^{25}$ through her skill in languages, her aptness as a pupil. It is her knowledge of French which makes her so valued since she can act as go-between, both carrying the word of Christ to her kin and helping the nuns perfect their skills in the Algonkian language. In returning her to her people with new powers of reading, writing, and telling the gospel, the missionaries were making use of, and recuperating for their own ends, the aboriginal practice of according women authority to speak in public assemblies. Indeed, it was the resistance of aboriginal

${ }^{24}$ She is known as "Magdeleine de Saint Joseph Amiskweian" ( [1640-1641], 1959, XX, pp. 126-7). "When she saw certain Jugglers breathe upon her sick brother,and sing to him, she only wept; as soon as these Charlatans had been driven away, the poor child began to laugh, indicating by her tears the horror that she had for their ancient superstitions, and showing by her joy the pleasure she took in seeing her brother inclined to have recourse to God" (XX, pp. 128-9).

${ }^{25}$ That this is her full name is suggested in the notes of Dom Guy Oury to his edition of the Correspondance ([1681], 1971, p. 124). The hyphenated name ironically invokes both that of the Virgin Mary, immaculate, and of Magdelene, the sinner, and so combines the double tropes of conversion in Mere Marie's discourse, that of ease of conversion, because always-already European and 'naturally good,' and that of potential infidelity in need of a strong shaping hand. 
women to their teaching, and the consequent difficulty in converting the tribes, that had induced the Jesuits to bring the Ursulines to New France (de l'Incarnation, [1681], 1971, pp. 117-8). By educating the women, it was hoped, the entire tribe would be saved from such 'diabolic' temptation, Christianized and francisized. Particularly important in this regard were the dual constraints of silencing women as social actors while encouraging them to reveal their most private thoughts in confession and receive instruction in how to understand them, so learning obedience and humility. Returning the girls with official presents, charged as ambassadors to their people, reinforced the new hierarchy being established of "Jesuits-Ursulines-aboriginal child-adult aboriginal" (Deslandres, 1987, p. 106).

Marie differs from the other Algonkians precisely in her refusal to lie, lie avoided by speaking transparently, that is, (as) French. Her lifestory, however, unfolds along the same lines as those of other girls inserted into these relations - sudden and total transformation upon baptism $^{26}$. "Progress" is equated with a sedentary life, with confinement within the domestic space of 'civilized' femininity. In her early letters, Mère Marie expresses surprise at the way the aboriginal girls accept the confines of the cloister. Though Marie Negabmat kept running away into the woods at first, after her Christianized father ordered her to return, she was transformed within two days into a model of piety ${ }^{27}$. At this point,

26 "Elles perdent tout ce qu'elles ont de sauvage si tôt qu'elles sont lavées des eaux du saint baptême en sorte que ceux qui les ont veues auparavant courir dans les bois comme des bietes sont ravis et pleurent de joye de les voir douces comme des brebis s'approcher de la sainte table pour y recevoir le véritable agneau" ([168I], 1971, p. 112).

27 "Elle n'y fut pas deux jours qu'il y eu un changement admirable. Elle ne sembloit plus être elle-même, tant elle étoit portée à la prière et aux pratiques de la piété Chrétienne, en sorte qu'aujourd'huy elle est l'exemple des filles de Québec" (de l'Incarnation, [1681], 1971, p. 95). Les Relations des Jésuites records the same transformation, but portrays baptism as an act of violence when Père Le Jeune threw Marie into the river for not obeying her parents ( [16401641, 1959,] XX, pp. 132-3); Aboriginal peoples did not punish their children, to Père Lejeune's great disapproval : he favoured a family structure of patemal authority (Anderson, 1991). 
Mère Marie stresses the success of the missionaries in establishing the power of the cloister. Nearly thirty years later, she admits to her son that only one out of every hundred girls who have come to them has been "civilized." When least expected, the girls climb over the palisade "like squirrels" ([1681], 1971, p. 802) and disappear into the forest with their parents. Being cooped up in houses makes them melancholy and ill $^{28}$. Despite these failures in her vocation, Mère Marie continues to uphold the importance of enclosure with the gendered and class hierarchy it constitutes, rather than to abandon the cloister to follow the aboriginals' itinerant life in the forest.

This gap between exemplum and actuality may also be a function of Mère Marie's eagerness to detect cultural similarity in visual signs ${ }^{29}$. Mimicry of gestures is how she measures the quality of Marie Negabmat's transformation : "elle tressallit de joye à la veue $\mathrm{d}[\mathrm{u}]$ pourtraict" of the Virgin Mary and prays twice, first in Algonkian with her friends, then with the French girls ([1681], 1971, p. 91). Agnes Chabwekwechich is considered exemplary for repeating the Christmas sermon to the children in the convent complete with gestures (Relations, [1640-1641], 1959, $X X, p p .134-5)$. What the aboriginal girls' readings of these gestural codes might be is elided in this text which focuses exclusively on the correct repetition of ritual forms. Were they manipulating the codes to their own profit, as the sons of Donnaconna had? (Cartier 1986, p. 143-145) What is the twentieth century reader to make of Mère Marie's accounts of how the girls showered the nuns with caresses as they never did their own

28 "C'est pourtant une chose très difficile, pour ne pas dire impossible de les franciser ou civiliser. Nous en avons l'expérience plus que tout autre, et nous avons remarqué de cent de celles qui ont passé par nos mains à peine en avons nous civilisé une. Nous y trouvons de la docilité et de l'esprit, mais lors qu'on y pense le moins elles montent par dessus notre clôture et s'en vont courir dans les bois avec leurs parens, où elles trouvent plus de plaisir que dans tous les agrémmens de nos maisons Françoises. L'humeur Sauvage est faite de la sorte : elles ne peuvent être contraintes, si elles le sont, elles deviennent mélancholiques, et la mélancholie les fait malades ([1681], 1971, p. 809).

${ }^{29}$ Significantly, the Ursulines did much of their teaching of Catholic doctrine to aboriginal students with the help of images illustrating Biblical narratives and the catechism. 
mothers ${ }^{30}$ and indeed had come to think of the nuns as "truly our mothers, we lack nothing with them"? ([1640-1641], 1959, Relations XX, pp. 138-9) Did they recognize their position as hostages and attempt to make the best of it? Was this duplicitous mimesis, playing up to the nuns in response to the latters' fantasmatic investment in transformation, only to get new clothes and attention showered upon them? These, however, were not sufficient incentive for Nicole Assepanse to leave her mother (de l'Incarnation, [1681], 1971, p. 96). Mère Marie records these contradictions without comment, demonstrating fantasmatic certainty in the cultural universality of gestural signs which she reads within her own narrative model of conversion as 'true (Christian) belief.

So much has Marie Amiskouevan become the 'civilized barbarian' that she has a French suitor and is on the point of assimilation. But the nuns appropriate her cultural fluency, her zeal in their service, for their ends and arrange her marriage to an aboriginal man, a student in the seminary. Moreover, they use her in the traffic in languages within their missionary aims of total conversion to translate French Catholicism downward. In the exchange of letters between New France and France, she figures in the textualization of this 'civilizing' project : this anecdote of her conversion written in French serves as exemplum in the Ursulines' continual petitions for funds ${ }^{31}$. The plea for help for the future is underwritten by the description of the always-already francisized aboriginal. Marie and other aboriginal girls figure as objects of

\footnotetext{
30 "On ne peut exprimer les caresses qu'elles nous firent, ce qu'elles ne font jamais à leurs mères naturelles" ([1681], 1971, p. 97).
}

${ }^{31}$ First narrated in the letter of 3 September 1640 to "A Lady of Rank" as testimony to the Ursulines' accomplishments at the end of their first year in Quebec, Marie Amiskouevan's story is related a year later (24 August 1641) in thanks for the charity bestowed and to "beseech" the convent in Tours yet again "[v]ous m'obligez infiniment de [la charité] que vous nous voulez faire" ([1681] 1971, p. I23). Repeated in Les Relations des Jésuites, this appeal for money is glossed with a narrative of its transformative effect. The little house and plot of land that will be provided for the seminarians will aid in their assimilation to an agricultural mode of life. "If such piety touch the hearts of many, the Savages will quit the forests to come to us : and the parents will give their children to the seminary" (Relations, [1640-1641] 1959, XX, pp. 126-7). 
demonstration for the miraculous transformative powers of Christian rhetoric and the perfect submission of the Ursulines to His will as instruments in this conversion. Encounters between 'native informants' and missionaries' master discourse involving questions of translation are reconstructed in a textual account that brings reader and native into a textual participation fusing external and indigenous cultural descriptions. Mère Marie's discourse oscillates between exemplum and prayer, constituting a subject of enunciation in the authoritative reportage of Amerindian life, abjecting herself in submission to the wealthy patron and the divine author ${ }^{32}$.

The potential betrayal of translation of Amerindian languages is contained in a troping that makes them 'sacred' and affirms divine authorship. The French nuns and priests do not leave interpretation exclusively to the aboriginal peoples but learn their languages themselves in order to speak more eloquently, to persuade more effectively. They write glossaries and grammars to fix knowledge so they will not be dependent on treacherous aboriginals or nativized French coureur de bois as interpreters (Delisle, 1975, p. 35). Mère Marie begins a letter to a fellow religious a year after her arrival in Quebec with a salutation in Algonkian which she immediately translates into French. These, she concludes the paragraph, are "à peu près ce que nous disons ordinairement à nos chères Néophites" ([1681] 1971, p. 108). The figure of linguistic difference with which the letter begins slides into one of commonality. Translating upward and downward, into and from the French, is synonymous for Mère Marie, for the rhetoric of the utterances is the same, to transport or, more precisely, to transfer (French) Catholicism, to encounter the sublime as an instrument of divine providence. In this trope, she rewrites Canada into the Roman empire.

Travels outward to the 'new' world are figured as travels back in time : New France is fused with Biblical time and place. Indeed, contrary

\footnotetext{
32 The ultimate phase in this narrative of the providential work of civilizing aboriginal girls involves Mère Marie de l'Incarnation's translation by the Catholic church into the realm of the Beatified for her miracles and visions, for her powers of eloquence in teaching and writing. An important document in the case for her Beatification was a letter from descendants of the Hurons to whom she had ministered.
} 
to others' perceptions that Canada is located in the regions of Hell, she finds it perfect Paradise ([1681] 1971, p. 112). She has been transported to the time of Christ under the Romans, to the period of early Apostolic fervour conflated with the later inspired work of the Church Fathers translating the Vulgate, and represents skill in the Algonkian languages as knowledge of the sacred and universal language, Latin. As she writes : "Nous faisons nos études en cette langue barbare comme font ces jeunes enfans, qui vont au Collège pour apprendre le Latin. Nos Révérends Pères quoique grands docteurs en viennent là aussi-bien que nous, et ils le font avec une affection et docilité incroiable" ( [1681], 1971, p. 108). This trope of inversion as infantilization is repeated in the many allusions to the blessedness of spirit among those who are to all appearances poor and naked in the new world. Study is difficult and humbling, but is made easier by "God's Grace" ${ }^{\text {"33 }}$. Learning to speak well (selflessly), putting on the drapery of rhetoric as in the figure of translatio, will lead ultimately to the authority of the spirit to persuade so that New France will become God's kingdom regained. It was also a potential site for martyrdom, a possibility Mère Marie, like the Jesuits, had constantly in mind ([1681], 1971, p. 94). All her hardships and deprivations were read as signs of possible ravishment of a different order, framed by the excess of the Counter-Reformation which translated extreme material suffering or sacrifice into the ineffable language of the mystical sublime. Barbarity is thus configured as sanctity. Translating downward into aboriginal languages is refigured as vertical translation into Latin, language of the ineffable. Even the forked-tongue translator may be converted when Latin becomes the universal Truth of the colonial encounter with spatial and temporal coordinates confounded in the process. This universal language is possible only by separating language and cultures so that Eurocentric ideas are exchanged in any and all languages. In such a process of displacement, the aboriginal languages are surplus signs taken as waste, infinitely replaceable and expendable.

These texts subsequently entered the European literary system in the guise of non-fiction as the 'truth' of 'discovery', producing innovation

33 "Nous étudions la langue Algonquine par préceptes et par méthode, ce qui m'est très difficile. Notre Seigneur néanmoins me fait la grâce d'y trouver de la facilité." ([1681], 1971, p. 112). 
within it, at a moment when Europe was inventing itself in spatial relation to the Americas, Africa and Asia, as well as in temporal relation to the Greeks and Romans. To locate in the texts of exploration and settlement the specificity of aboriginal perspectives in the colonial encounter requires a shift in the object of investigation to the colonized in the production of de-colonized knowledge. Reconfiguring the subject-position of indigenous peoples as colonized, however, does not undo the ideological work of their exclusion as subjects to and of their own historical making. At the centre of this exclusion is the politics of translation implicit in such colonial texts as the letters of Mère Marie de l'Incarnation where the translator refuses to engage with the rhetoricity of the source text of Marie Amiskouevan, to consider where its social logic ordering the relations between words may work according to a different economy. Gestures are read with infallible certainty : the potentially disruptive logic of the Algonkian languages is e-rased in the trope that turns them into Latin, the language of imperial truth.

\section{Re/version}

Almighty Voice and His Wife reads as an inversion of such a theory of equivalence. Daniel David Moses reverses the object of investigation from the colonizer to the colonized in an attempt to undo the ideological work of their exclusion as subjects to and of their own historical making. European rhetorical forms are re-ordered in Amerindian rituals that constitute meaning as event rather than as representation. The performative mode of his text brings readers and actors into a textual participation by separating rather than fusing external and indigenous cultural descriptions. Performance is written out, however, which writes aboriginals into the discourse of empire to question its categories and values. Viewing bilingualism not as a slippery slope leading to delusion, where translation is figured as loss, Moses presents a theory of translation as creative difference, where ambiguity opens up a potentially generative play of illusion. Cultural transmission for aboriginal peoples may be assured through the creative enhancement of translation as afterlife beyond colonization in a process of recycling as regeneration through decay and dismemberment.

Language choice, translation, is a site of conflict. The language of the master is masterfully wrenched to a different effect as Moses 
addresses the problem of self-representation when one persists as a stereotype 'in translation'. The obligation to 'speak white' in the Interlocutor's commands to Almighty Voice - "Come on, use the Queen's tongue" $(1992$, p. 54) - is countered when he continues to perform a Cree ritual, repeating its gestures, though not always its language. This failure in representation points to an otherwise invisible rupture in the figuration of the 'indigene'. English has become the language of intertribal communication but its hegemony is being challenged. For it has become the instrument in which the First Nations collectively wage a political struggle for land and self-government. In a strategy of decolonization, words are opened to the play of cultural difference, resignified heterogeneously in the same 'national' language, as in Moses's marvellous word play on "ghost" which reanimates clichés to make English an aboriginal tongue.

Straining not for the translative sublime, like Marie de l'Incarnation, Moses offers a different kind of catharsis in the play of irony. Norms, barriers, are made to be broken, transformed. Against a model of vertical translation producing subjugation, Moses develops a horizontal model of translation between aboriginal cultures privileging creative bonrowing. For the topic of his play is an incident from the history of the Cree people's conflict with hegemonic Euro-Canadian culture while Moses himself is a Delaware ${ }^{34}$. His play stages a double act of translation both supraduction, in which the European language is reshaped by aboriginal cultural values, and trans-duction, in which someone from an Iroquois community writes Cree history and ritual - with the acknowledged help of translators - the Cree language then retranslated in the published script into the dominant language, English. In performance, however, the Cree is untranslated, producing differentiated positions for spectators distinguished on the basis of language. This

${ }^{34}$ Originally from the New Jersey/Pennsylvania area, the Lenni-Lenape or Delaware, an Algonkian-speaking people, came north to Canada as United Empire Loyalists. The largest group settled at Moraviantown in south westem Ontario, with a smaller group, to which Moses belongs, settling on the Six Nations reserve of the Iroquois confederacy for whom they had previously served as "Peacemaker" to the Iroquois "Warrior". A minority among the Iroquoian-speaking Six Nations, the Delaware language now has few speakers. For this history see Hitakonanu'laxk and O'Meara. 
palimpsestic overwriting is a subversive move to work with and against the conqueror's language so as to render visible substantially different cultural assumptions and disrupt the hierarchy established through Mère Marie's linguistic theory of transparency. Moses analyzes performatively the material modalities of communication with all their contingency. Two metaphorical machines wrap around each other. The translator's duplicity is not a matter for a firm controlling hand but a feint making possible survival within a logic of contradiction that deflects such power to fix and define.

A number of Marie de l'Incarnation's tropes are taken up, their presuppositions exposed and transformed, most specifically, that of the faithful handmaiden with its accompanying figure of enclosure. An important addition to Moses's version of the story of Almighty Voice ${ }^{35}$ is the attention given to his wife, White Girl, which is Moses's homolinguistic translation of the personage known in historical documents as Pale Face. The play demonstrates the importance of what Jeannette Armstrong terms "soft power", that is the feminine power of cultural creation and transmission, as the epigraph affirms. Significantly, the play is dedicated to Moses's grandmothers. It ends with a scene in which the character Almighty Voice, who has endured a long afterlife playing his ghost in the character of Mr. Bones in a Medicine Show, dances on stage. Literally dead, he lives on 'in translation'. Meanwhile his wife gathers her costume from the Show where, dressed as a Mountie, she plays the Interlocutor (police and show barker simultaneously). She then holds it aloft, presenting a child-shaped bundle to the audience. Through the magic of performance, the cloth is transformed from the uniform, symbol of oppression, to swaddling clothes, promise of continuation. This marks a shift from death to new life which is the narrative movement of the play.

White Girl is no subservient figure : "pretty fierce for a little girl" (Moses, 1992a, p. 64). An assertive interrogator in this second act, she has been an active instigator in the first, an escapee from the convent school, breaking through all the walls that Mère Marie's successors have put up

\footnotetext{
${ }^{35}$ Perhaps the most famous of these focusing on the male hero is the story "Where is the Voice Coming From?" by Rudy Wiebe.
} 
to prolong the cultural genocide. The hunger she feels in the school, the absence of game to hunt on the prairie, all point to the fatal effects of fencebuilding for the Amerindians from their perspective. With her mother-in-law Spotted Calf, moreover, White Girl is the keeper of ritual traditions and knowledge. Her power vision or "good medicine" protects Almighty Voice from the pursuing police, though her "bad medicine" as the once-baptized "Marrie" may have made him more vulnerable to their power. A frequent violator of the pass regulations designed to contain aboriginals on reservations, Almighty Voice has broken out of jail where he has been confined for killing a cow for their wedding feast, an insurrection that ultimately finds him encircled by more than one hundred Mounties with a cannon. A narrative of outlaws seeking an outside where they will not be surrounded, the captivity figure is now presented from the angle of those resisting it, breaking through the circle. The play stages the conflict of colonial conquest in this representation of the final incident of armed rebellion by aboriginals in western Canada a century ago while reasserting aboriginal cultural practices with the prohibited Ghost Dance and slippery Trickster. In this, Moses inserts the eclipsed aboriginal understanding of closure as death into the Eurocentric concept of 'civilization' to expose the differential political effects of 'capture'. Insurrection is implicated in a move from translatio to interpretio, from the singular truth of the Aufhebung to the proliferation of contradictory versions necessitating interpretation within a historicized pragmatics.

The trope of invisibility is also examined through the contrasting logic of European and aboriginal cultures. The telescopic vision of the Mounties which allows them to see further into what is and so enlarge the circumference of their surveillance contrasts with the dream power of White Girl to foresee the future and make things happen. These two modes of vision - two different logics and temporalities - coexist, each ordering reality differently. From the prophetic perspective of medicine power, the problem of the "Vanishing Indian" - that the "only good indians are the dead ones" (Moses, 1992a, p. 68) (or "the ones who are sainted" Moses, 1992a, p. 89) - is only apparently so. As the Interlocutor proclaims, and the play enacts, "the most acclaimed magical act of the century [is] the Vanishing Indian" (Moses, 1992a, p. 58) who persistently reappears in a different form, not the disembodied Christian "Holy Ghost". Aboriginal culture only seems invisible to those who will not see. The complex play on appearance and reality, foregrounded in the white 
masking of the characters in Act 2 in a series of plays within the play, through which the matter of 'passing' is explored, contrasts with its treatment by Marie de l'Incarnation. While she takes appearances for the real and reads aboriginal bodies as francisized, Moses creatively works with the problematic of representation as re-presentation in a specific socio-political instance of address to examine the manipulation of corporeal surfaces. As the Ghost says of the Interlocutor "her touching masquerade seemed aimost real" (Moses, 1992a, p. 82). She has become almost 'white,' though as the costume shows, the inverse of the 'apple' white outside but red within ${ }^{36}$. The performer's body is the primary signifier in which these competing narratives are played out. Against the transcendence of the disembodied word in the service of spiritual union in Mère Marie's theory of language, Moses foregrounds the embodied word in order to probe the relation of verbal and gestural signs. In this mise-en-scène which is a mise-en-abyme that foregrounds such 'acting out of character' in the trope of cross-dressing in terms of both race and gender, the 'tragedy of representation' as lack or absence is reversed in terms of its mimetic display in a subjunctive world of 'as if' and, under the name of play, takes back everything, including the cultural genocide of aboriginals.

The logic of the masquerade is the logic of the supplement which overturns the hierarchy of firstness and secondness, of the One and the many, to posit the logic of the series, of variation. The gap in the interval between two enunciations is a sign of excess in the layering of discourses which constitutes them as partial, both incomplete and virtual, mutually interdependent within an historical instance of enunciation. Moses's investigation of representation extends to the slipperiness of language, the difficulty of holding anything fixed, even a proper noun. "Names, names, they're all the same", the Interlocutor parodies the Euro-Canadian perspective : "Dead man, red man, Indian. Kisse-Manitou-Wayou, Almighty Voice, Jean Baptiste! Geronimo, Tonto, Calijah! Or most simply, Mister Ghost" (Moses, 1992a, p. 55). This proliferating chain of signifiers fails to contain the character, however, despite the seeming fixity of the clichés. Under the name of Ghost alone he performs a number

36 "Apple" is a pejorative term for the acculturated aboriginal. 
of roles in the Medicine Show, not only those of Almighty Voice and his friends, but those of the attacking Mounties and of the transvestite, Sweet Sioux, making use of a number of different performance styles from different racial and social milieux; minstrel show, vaudeville, folk singer, western, pow wow fancy dancer. Contradictions proliferate : Jean Baptiste, as White Girl says, is the "name of one of their ghosts" (Moses, 1992a p. 22), a christianized "Holy Ghost". Conversely, Almighty Voice in jail is lost "like a ghost" (Moses, 1992a, p. 45). Ghost is a term aboriginals use for white people. The imposition of 'civilization' on the two characters, their possible acculturation, is signified in their 'saintly' names. Ghost stories, however, are an important narrative form on the Six Nations territory (Greene, 1975). Refusing the position of ineffable in the service of the nation's integrity, Moses attempts to make ghosts visible. This necessitates an examination of the other side of language, the cultural matrix that regulates the conditions of meaning-making. His challenge is to foreground eclipsed social values within the discursive modes of the dominant language. The encounter productively disorders the value distinction (distribution) between White and Amerindian cultures.

"To be seen is the ambition of ghosts", Moses writes as epigraph to another play, Coyote City. And he continues there with a story : "The ghost said to Coyote. Here we have conditions different from those you have in the land of the living. When it gets dark here, it has dawned in your land and when it dawns for us it is growing dark for you". The complex stereoscopic vision is available to Coyote the trickster who, as shape-shifter, embraces contradiction in his role as go-between. The plasticity of Trickster is such that s/he can transform into any shape - a fluctuating identity (Radin, 1969, p. 165). Highlighting the connection between the tropes of inversion and of visibility, this epigraph also points to the cultural significance of one of the formal modes of representation in Almighty Voice, that of the shadow play, which focuses specifically on altered angles of vision and different states of being. Possibly, this constitutes a reworking of Plato's allegory of the cave so influential in Western thinking on representation as repetition, for it reverses his privileging of light as Truth to convey the enhanced power of seeing in the dark among the many copies and gives greater authority to the domain of illusion. In addition to the shadow play of the final scene, where the ghost dances for the baby's arrival, there is a shadow play at the end of the first act entitled "His Vision". In gesture only, it enacts the incident of 
Almighty Voice's crossing the police lines at night, invisible to them in the dark, moving behind the screen of representation to a spectral tipi where sit White Girl and her child. Almighty Voice breaks out of the circle of confinement aided by the cover of the dark which makes him invisible to the police. That the dark is valued positively is further conveyed by the final image where the religious allegory of Marrie/Salome/White Girl and John Baptiste/Almighty Voice in which a woman kills a man (her "bad medicine"), has been translated into the terms of Cree rituals of cultural and spiritual power in which a woman gives life to a child. However shadowy it may be, this holds the promise of life to come, prophesying a future for the "Vanishing Indian". Certainly it proclaims that the heart of White Girl is not on the ground. For it counters her vision in the shadow play of the first scene of Act One when, confined in the school made of stone (Moses, 1992a, p. 19), she foresees Almighty Voice's death and the moon turning to blood.

Against the trajectory of the historical narrative of aboriginal decline in the first act, marked by the expansion of the prison walls so that the Eurocanadians "even turn the prairie into a jail" (Moses, 1992a, p. 26) and a place of death, is performed in the second act a ceremony of renewal, functioning like the great Midwinter Festival of the Iroquois as a new fire rite of renewal, a Dance of the Dead or Ohigwe, to cure paralysis or the spiritual death of melancholy (Kurath, 1968, p. 48). Winter is also the sanctioned season for storytelling (Hitakonanu'laxk, 1994, p. 41). If the epistolary genre constitutes Marie de l'Incarnation's translator as subjected to the higher authority of the divine addressee, the combination of storytelling and performance in Moses's play reconfigures the enunciation of the translating subject as polyvalent within the play of social forces. Even as the first act tells a story about some words to make visible the aboriginals' experience of colonization as spiritual and physical death, the second act meditates on the role of performance in opening meaning to an exchange between languages that is life-enhancing. Translation as performance goes beyond the creative expansion of aanikohtamowin, to introduce another modality of examining the silent and invisible force of cultural rhetoric with its politics of address. Performance enables Moses to set words against gesture, voice against body, in a complex layering that turns the rhetoric of imposition against itself to expose it as rhetoric and evaluate its technologies and effects. Translating the codes of empire downwards, in the barbed lines of the 
Interlocutor, foregrounds how anyone may learn them, mimic them, yet not be contained by them. The European doubling and projection in the representation of the aboriginal as displaced European is performed by the Amerindian in a depropriative mimesis or strategy of reversion. Reciting them back to a Eurocanadian audience gives them yet another spin by confronting spectators with the limitations of their cultural knowledge. Performance thus establishes a discontinuous space transected by a number of different boundaries, an opening of the field of meaning for the audience's interpretation, in what constitutes a breach of the fourth wall.

Performance, within the current discursive field in Canada functions as a sign of aboriginal authenticity, for orality is a fiction of firstness constituting identity as First Nations in a social contract founded in the legible. As such it has power within a struggle over political rights. Traditional aboriginal performance occurs as both storytelling and ritual. Theatrical performance, however, constitutes a European high art form. A tension between cultural performance and aestheticized theatricality informs the complex structures of address of Almighty Voice and His Wife. As co-director of the Committee to Reestablish the Trickster (1990), Daniel David Moses organized a series of workshops ${ }^{37}$ to encourage aboriginal playwrights to produce cross-over works, intersemiotically translating traditional storyteiling techniques with their enigmatic teaching form $^{38}$ into the agonistic models of dramatic conflict of aesthetic texts.

37 These workshops had titles such as "Storytelling for the Stage" and "Re-establishing the Voice : Oral and Written Literature in Performance". In discussing features of aboriginal writing, Moses confirms the importance of Trickster in his plays as extending both verbal and visual possibilities: "The trickster is the embodiment of our sense of humour about the way we live our lives. It's a very central part of our attitude that things are funny even though horrible things happen". Performance and "the example of traditional Native story-telling... has been for me a freeing thing. The pieces I write look like plays or poems or short stories, but I'm interested in how they sound and how they work when they're spoken" (Moses and Goldie, 1996, pp. xiv-xv).

${ }^{38}$ As you read the stories, as you listen to them it is expected that you make your own interpretations and draw your own conclusions as to the meanings within them... There is a strong Native belief in not interfering with others, but instead in giving them the chance to have their own thoughts, to make up their own minds and express themselves freely. Storytelling to us is a community experience, a 
Performance is a space for gathering and dispersing energy that effects a transition or transformation. A turning in the here and now that introduces a breach in regular social relations, moving into the betwixt and between to furnish a critique of the crisis, performance recontextualizes and establishes fields in which to situate a gesture, a body, a word. As such, it is a repetition with a difference, a transformance emphasizing process and action, along the model of translation as rewriting ${ }^{39}$. Initiation rites and political ceremonies, which are considered to be social dramas, effect a transformation in the status and bodies of the participants in the action, whereas aesthetic drama works its transformations on the audience of the performance (Schechner, 1988, p. 171). Moses's theatrical production, like those of a number of First Nations playwrights, works between these two modes of enunciation, producing transformations on both levels for the aboriginal actors constituted as subjects of enunciation, and for audiences turned into participants and initiated into new cultural knowledges or a critique of institutionally received knowledges.

Indeed, the question of subjectivity is central to performance which is concerned with the manipulation of the fragmented body and of space so that they become fluid, transformed into event. Though limited somewhat by a fictional character, performance initiates a play of desire with the performer as catalyst. Through the play of doubling and repetition are constructed spaces for the projection of different postures of desire wherein subjects-in-process constitute themselves through investment in different objects of desire and emerge from the 'event' transformed (Feral, 1985, p. 135). Seeking not to say something, but to set in place a series of relations among subjects through play with a variety of transitional objects, performance poses a deterritorializing gesture, forcing an opening that reorients relations of centre and periphery (Feral, 1985 , p. 138). Setting aside representation, performance stages social roles as models for demonstration and critique of social technologies. Through the play of the "fictive body" manipulated by the actor rehearsing her own

coming together of people, to share in our past, our way of life, and in and of ourselves as a people". (Hitakonanu'laxk, 1994, p. 41)

${ }^{39}$ I am summarizing briefly here arguments on translation as performance in "Reappropriation as Translation" (Godard, 1990). 
staging of the imaginary as a subject-in-the-making, the fixed subjectivity of scripted social behaviours or roles is unravelled. Enunciations are conceptualized as process rather than finished utterances within the making of meaning for social subjects. The criterion of performability in the theatre changes the function of the linguistic utterance so that it becomes only one sign in relation to others in a web of sign systems. The sense of the individual units of meaning depends on their connection within this network which foregrounds the imbrication of text and interpretation, performance enacting a movement beyond the text which reveals itself to be open to multiple interpretations, not tied to the prior letter of the law. Performance introduces into the consideration of translation a movement from a constative theory of discourse which frames truth claims in terms of fidelity or resemblance toward a consideration of meaning-making within the terms of appropriateness in response to the conditions of address or performative theory of discourse, that is, to a consideration of the ethical or political effects within a field of "clashing languages" (Bakhtin, 1981). Your word against mine.

This brings me to the important second act of Almighty Voice and His Wife where the narrative of an historical event from an oppositional perspective that exposes the deadly constraints of living a history under conditions not of one's own making shifts to a Brechtian defamiliarization of performance where that history is rehearsed in a number of stereotypical Euroamerican representational modes. The Interlocutor's pedagogic discourse punctuates with details of their finer points the different performance styles to underline their conventionality, their culturally specific pertinency as modes of exclusion. Superimposed on them in a theatre of cultures is the Ghost Dance, aboriginal ritual that disrupts the generic contract of Eurocanadian drama by substituting communal participation for individual psychologized crisis. In a syncretic move, Moses layers a variety of 'national' rituals, from the Cheyenne preface to the attribution to the Cree of a ceremony of the Sioux brought north to Saskatchewan by Sitting Bull, after his defeat at Little Big Horn. Moses invokes him as "Chief Shitting Bull" in a final outburst of high invective (Moses, 1992a, p. 80). The massacre of the Ghost Dancers at Wounded Knee is introduced in the gallows humour of Act Two, Scene One titled "Ghost Dance", when the Ghost, relating the phases of Almighty Voice's last stand against the police, describes how he "crawled out of the pit" he had dug to protect himself from the gunfire. "Wasn't 
much good against a seven pound cannon, now was it?" The Interlocutor replies : "His leg was gone. Talk about wounded knee! The bones were shattered, pulp" (Moses, 1992a, p. 73). The effect of such historical references is to constitute this as a cultural performance, in that it invites spectators to merge the space of their lifeworld and the imaginary space of theatricality with the 'real' space in which they are living during the performance, the space-time of 1897 in the Michinis Hills near the One Arrow reserve. Such a conflation of representational, theatrical and cultural spaces as event is reinforced by the physical presence of stage features. The mechanism of such referentiality, however, works only when the appropriate cultural context is supplied by the audience. The spectator is interpellated differentially depending on whether $s /$ he connects the stage space to the conventions of performance and so aestheticizes the action or whether s/he links them also to the historical events of Wounded Knee as site of the Ghost Dance massacre as well as site of the 1960s political struggles of the American Indian Movement. The Interlocutor is more explicit in framing the conditions of aesthetic performance as spectacle within the technology of the gaze of empiricism and imperialism than in keying the audience for aboriginal ceremonial ${ }^{40}$. In making the latter connection, aboriginal members among the racially and culturally mixed Toronto theatre public of Native Earth Performing Arts would constitute themselves as subjects of the enunciation, a collective historicized subject who actively participates in the transmission/transformation of discourses.

Counterpointing the many versions of the spectacle, theatrical version of the panopticon, is the participatory ritual of the Ghost Dance. One among a number of messianic religions which emerged in the nineteenth century in response to what Dickason terms the "upward spiral of regulation" (Dickason, 1992, p. 315) after the defeat at the Battle of Batoche (1885) of Big Bear's campaign to unite the Amerindians and of the Metis' hope of a nation, the Ghost Dance was a "cultural reaffirmation in the face of strange new forces" (Dickason, 1992, p. 237). Such movements worried officials for they strengthened the peoples' inner

\footnotetext{
${ }^{40}$ The Interlocutor sums up the seige where Almighty Voice is surrounded by the RCMP : "Imagine Red coats and wild Indians. What a spectacle! Where are my glasses?" (Moses, 1992a, p. 74) S/he is silent about the Ghost dance ritual, however.
} 
resources to withstand the intensifying onslaughts on their culture. "The traditional way, far from disappearing as officials hoped, was reincarnating in different guises" (Moses, 1992a, p. 287). Rising on the American prairies in the $1880 \mathrm{~s}$, the Ghost Dance syncretically linked new practices with traditional beliefs and forms. The white robes worn by Ghost Dancers were adapted from the Mormons. The rituals themselves, exhausting dances which induced ecstatic trances in the dancers within the traditional sacred circle, stressed their individuality in a quest for etemal life. In the trance under the medicine man's hypnosis, individuals communed with the spirit world and had visions of their friends who had died. This vision made them personally invulnerable to the violence of white culture. Prohibited in Canada after 1906 (Dickason, 1992, p. 287), with its focus on reproducing a state in which the dancer moves through death to a transformed existence, the Ghost Dance proves an apt metaphor for traditional aboriginal culture which was driven underground by such oppression.

Making the ghosts dance again is both to transmit aboriginal tradition and to symbolize the dynamic and creative elements of a living aboriginal culture. Literally and figuratively, to dance is to commune with the dead souls and communicate visions of those who have died, yet are alive in the spirit world, to the world of the living. This is another temporality and subjectivity than the Eurocanadian, not a singular embodied existence, nor a disembodied existence founded in the dualism of body and soul, but a permeability of boundaries between spirit and matter, now and then, between languages and cultures. Significantly, the Cree language is concentrated in the opening and closing scenes of Act Two, in the opening scene, titled "Ghost Dance", where he replies to the Interlocutor's taunts by ordering her away so he can finish his dance ${ }^{41}$, line which returns as refrain at the end of the play. That the Interlocutor shifts

4) "Ghost : Awas kititin ni-nimihiton oma ota. (Go away. I'm dancing here)... Nahkee. Kawiya-(ekosi). Ponikawin poko ta kisisimoyan. (Stop. Let me alone. I have to finish my dance)" (Moses, 1992a, pp. 54-5). 
languages and symbolic codes and answers him in Cree in the final interchange of the play ${ }^{42}$ signifies the transformative effect of the dance.

A dance of resistance, of shape shifting, of metamorphosis or transformation, the Ghost Dance falls within the purview of Trickster's double-voiced logic (Radin, 1969, p. 148), a logic of contradiction, in which life and death, inside and outside, divinity and buffoonery, folly and cunning are coterminous, different twists of a single "moebius strip" (Vizenor, 1988). Appearances are unstable in this logic, for something may well be the opposite of what it seems. Moses both aphoristically sums up the historical significance of the Ghost Dance religion and invokes the Trickster in the last line of Scene Eight titled "Standup" when Almighty Voice says : "I'm a dead Indian. I eat crow instead of buffalo" (Moses, 1992a, p. 95). This sentence is a complex example of the translation effect, or intersemiotic translation working through the trope of inversion. In general English usage, "eating crow" is the equivalent of "eating shit". There are double cultural inflections at work here : "eating crow" in the lexicon of the prairies means biting into the Trickster. The logic of inside out privileging contradiction rather than opposition specifically invokes Crow, the revered messenger from the spirit world (Mooney, [1965], 1986, p. 232), who is a figure celebrated in Crow dances where he is linked with the messiah, dances which form part of the Ghost Dance ceremonies among some Cheyenne groups (Mooney, [1965], 1986, p. 187). Crow it is who has breathed life into Almighty Voice's Ghost, the "skeleton crew", to attempt a performance of "number seven", a dance in scene three. Seven, incidentally, is the sacred number of leaders in the Ghost Dance. In this scene, "this Almighty Gas character" (or "big fart", as he calls himself to White Girl, invoking Trickster (Radin, 1969, p. 140) in contrast with the ghostly white god) "joins in on the season's carnival of ruin" (Moses, 1992b, p. 68). The carnivalesque contradiction played out in these puns is that what appears dead, according to the binary logic of the Christian religion which separates body and soul, is from within an aboriginal perspective most vibrantly alive, both more embodied and alive in more than body. "Eating crow" is not just eating a bony skeleton

42 "Ghost: Piko ta-ta-wi kisisomoyan ekwo. (I have to go finish dancing now). Interlocutor : Patima, Kisse-Manitou-Wayou. (Goodbye, Almighty Voice)" (Moses, 1992a, p. 96). 
rather than a fleshy animal, but a sharing in the metamorphic power of Trickster. Instead of a figure of death-in-life, the ghost playing tricks with death becomes a figure of life in excess of death. Playing on the ambiguities of the Ghost as both figure of the sacrifical victim in Eurocanadian narrative and figure of spiritual renewal in aboriginal culture, Moses takes up the mechanisms of racism, the jokes, slurs and invectives, and spins them around, inside out, to play them back to a white theatre audience interpellated as the 'you' of address. Affirming the magic power of the word to transform, this functions as a discourse of decolonization. Eating crow, the aboriginal has Trickster's power vision that shifts shapes, re-turns the spectatorial gaze by quoting the white man's words back to him (Moses, 1992a, p. 94), restaged so as to produce the Amerindian as subject actively ordering discourse. Far from disappearing, the ghostly Indian is dancing again in new disguises, transforming him/herself in the logic of variation.

Humour as defiance - this is the rhetoric of the "comic holotrope" that Chippewa writer Gerald Vizenor connects with the Trickster. His explanation of the trickster narrative, arising in "agonistic imagination" as "a wild venture in communal discourse, an uncertain humour that denies aestheticism, translation and imposed representations" (Vizenor, 1988, x), echoes Paul Radin's earlier account of the parodic and satiric bent of the Winnebago Trickster "ridiculing traditionally accepted order" (Radin, 1969, p. 152). Indeed, Trickster violates "fixed boundaries of custom and law" (Radin, 1969, p. 185), resists all boundaries to remain "open in every direction" (Radin, 1969, p. 188), a "promise of differentiation" (Radin, 1969, p. 168). This principle of presenting "various points of view", discourses within discourse, is what enables a writer to "elude historicism, racial representations and remain historical," as Vizenor comments (1988, xi). Moses has taken up Trickster's challenge to make visible this ramifying rhetoric of aboriginal culture and so refracts English making it a translated language. Aboriginal concepts are exchanged in any language, especially in English. As principle of differentiation, Trickster is interpreted anew by every generation (Radin, 1969 , p. 168). Indeed, under the sign of Hermes, or heterotopia, "traduction", the mode of transformation specific to literary texts, works the combinatory logic of generation itself, "dilue[nt] les anciennes figures et compose[nt] formes ou formules inattendues et rétrospectivement 
nécessaires... d'une science $d u$ vivant" (Serres, 1974, p. 16). Interpretio displaces translatio.

Asserting control over the discourse, over the representation of history, over the categories concerning identity formation, is a crucial tactic for a subaltern group to oppose hegemonic practices. Identity is no stable effect of a coherent entity but is constituted through the technology of language where the ' $T$ ' or subject of enunciation remains contingent and provisional to institutional policies and practices articulated in historically differentiated discourses subject to contestation and to change. Variation is marked by a functional shift in a sign system constituting a discursive displacement with a transformation in the relation of object and subject of knowledge. Tracing localized economies of damage and neglect in writing as resistance challenges the monopoly of discursive practices and articulates different conditions of possibility which make visible the limits of dominant fictions of the real. Translation as resistance, then, would be a tactic of intervention in what constitutes the basis of 'linguistic' as well as 'national' identity in Canada.

Ghosts are dancing, Trickster reigns at Spadina and Bloor in downtown Toronto. Moses, though, does not speak Delaware. In fact, there are too few speakers of the language now to constitute a linguistic community. Moreover, in his theory of language as in Marie de l'Incarnation's, aboriginal languages remain surplus signs, despite cultural difference in the conditions of language use. They are, however, within an economy where loss and gain are not the only terms for conceptualizing change or distinction. Rather within a regime of maximized exchange there is a theoretically infinite productivity not only of values, but of forms of exchange of values. Though Moses would locate cultural difference under the sign of Trickster, his/her principles of energy, of fluid boundaries and fluctuating identity, find analogues in the grammar of Algonkian languages with their emphasis on verbs that highlight action and on the addressee rather than the speaking subject. I've twisted the moebius strip inside out again with this paradox. In yet another twist, while I am studying Aanishinaabemowin, Daniel David Moses has just published a new play called, in echo of my argument, Brébeuf's Ghost.

Do linguistic boundaries necessarily coincide with cultural borders? Can a culture survive without a language? What constitutes 
cultural fluency? These are the thorny questions raised by the two examples I have analyzed which are respectively the translation of language but not culture and the translation of culture but not language. "Language is not everything", as Gayatri Spivak reminds us, merely a clue to the point of dissolution of the boundaries of the self. Attending to rhetoric - the established modes of address - as it works in "the silence between and around words" is necessary to constitute a model for a different language that acknowledges its foreignness and avoids repetition of the ready-made (Spivak, 1993, pp. 180-1). This ethical project of attentiveness to particularity also necessitates full consideration of the specificity of language whose syntax codifies a logic of relations, as in the case of the Algonkian languages where the marked category is that of the object of address rather than the subject. For differentiated knowledges, different positions for subjects are produced in the dynamic relations of language to culture with a more layered knowledge produced for the subject who comprehends both cultural and linguistic codes. Such discontinuous spaces of language and culture formulate a challenge to any "transcultural universal" (Bassnett, 1993, p. 159) of meaning-making. The full implications of this argument for cultural difference have not been addressed here in that my argument has been presented through two texts rather than through a series of examples. That my analysis of the differentiated models of semiosis or translation has been so restricted constitutes a limitation in its tendency toward a binary model of opposition between a logic of identity or equivalency and a logic of non-identity or contradiction. To demonstrate my contention that translation theories are constituted in a particular historical instance of enunciation from within a dynamic field of variation will necessitate further analysis of other moments in the history of translation in Canada.

York University

\section{References}

ANDERSON, Karen (1991). Chain Her By One Foot: The Subjugation of Native Women in Seventeenth-Century New France. New York, Routledge.

ARMSTRONG, Jeannette and Douglas CARDINAL (1991). The Native Creative Process. Penticton, Theytus. 
BAKHTTN, Mikhail (1981). The Dialogic Imagination. Ed. Michael Holquist. Trans. Caryl Emerson and Michael Holquist. Austin, U Texas P.

BASSNETT, Susan (1993). Comparative Literature : A Critical Introduction. Oxford, Blackwell.

BASSNETT, Susan and André LEFEVERE (1990). Translation, History and Culture. London, Pinter.

BIRNEY, Earle. ([1947], 1975). "Can. Lit.", The Collected Poems of Earle Birney. Toronto, McClelland \& Stewart.

CARTIER, Jacques (1545). Brief recit (deuxième voyage). Paris, Ponce Roffet. Rpt. in Relations : Edition critique, pp. 124-190.

(1598). Discours du voyage (première relation). Rouen, Raphael du Petit Val,. Rpt. in Relations : Edition critique. pp. 94-122.

(1540). "The Third voyage of discovery made by Captaine Jacques Cartier, unto the Countreys of Canada, Hochelaga and Saguenay". Trans. Richard Hakluyt. In Principall Navigations. 2nd ed. Vol. 3. pp. 232-37. Rpt. and Trans. in Relations : Edition Critique. pp. 236-246.

(1986). Relations : Edition critique. Ed. Michel Bideaux. Montreal, Les Presses de l'Université de Montréal.

([1580], 1975). A Shorte and briefe narration of the two Nauigations and Discoueries to the Northwest partes calle Newe France. Trans. Florio. The English Experience No. 718. Amsterdam and Norwood, N.J., Walter J. Johnson and Theatrum Orbis Terrarum.

. ([1924,] 1993) The Voyages of Jacques Cartier. Trans. H.P. Biggar. Intro. Ramsay Cook. Toronto, University of Toronto Press.

CHEYFITZ, Eric (1991). The Poetics of Imperialism : Translation and Colonization from The Tempest to Tarzan. New York, Oxford U P. 
DE CAMPOS, Haraldo (1982). "Mephistofaustian Transluciferation". Dispositio 7, nos 19-2, p. 42-60.

DE L'INCARNATION, Mère Marie ([1681], 1971]). Correspondance. Ed. Dom Guy Oury. Solesmes, Abbaye Saint-Pierre.

(1985). "La Relation de 1654" in Ecrits spirituels et historiques. Vol. II Ed. Dom Albert Jamet. Quebec, Les Ursulines. (1967). Word From New France: The Selected Letters of Marie de I'Incarnation. Ed. and Trans. Joyce Marshall. Toronto, Oxford.

DESLANDRES, Dominique (1987). "L'éducation des Amérindiennes d'après la correspondance de Marie Guyart de l'Incarnation". Studies in Religion/Sciences religieuses 16, 1, pp. 91-110.

DELISLE, Jean (1987). La traduction au Canada 1534-1984. Ottawa, Les Presses de l'Université d'Ottawa.

(1975). "Les interprêts sous le régime français". Mémoire de Maîtrise, Université de Montréal.

DICKASON, Olive (1992). Canada's First Nations : A History of Founding Peoples from Earliest Times. Toronto, McClelland and Stewart.

FERAL, Josette (1985). "Performance et théatralité : le sujet démystifié". In Théatralité, écriture, mise en scène. Montreal, $\mathrm{HMH}$.

GÉRIN-LAJOIE, Antoine (1874). Jean Rivard (1862). Montréal, J.B. Rolland.

GODARD, Barbara (1990). "The Discourse of the Other : Canadian Literature and the Question of Ethnicity". The Massachusetts Review. XXXI, Nos. 1-2, pp. 22-31.

(1981). "The Oral Tradition and National Literatures". Comparison 12 (Spring), pp. 15-31. 
(1990). "Reappropriation as Translation". Canadian Theatre Review, 64, pp. 22-31.

GRAMSCI, Antonio (1984). "Notes on Language". Trans. Stephen Mansfield. Telos 59, pp. 127-150.

GREENE, Alma (1975). Forbidden Voice. Tales of the Mohawks. Toronto, Dent.

HAKLUYT, Richard (1584). Discourse of Western Planting. London.

(1589). Principall Navigations., Voyages, Traffiques and Discoveries of the English Nation. London. Enlarged ed. 3 Vols. 1598-1600.

HITAKONANU'LAXK (1994). The Grandfathers Speak : Native American Folk Tales of the Lenapi People. New York, Interlink.

ISMAIL, Jam (1986). Diction Air, Vancouver.

The Jesuit Relations and Allied Documents : Travels and Explorations of the Jesuit Missionaries in New France 1610-1791 (1959). (bilingual ed.) Ed. and trans. Reuben G. Thwaites. Vol 20, 21 (1640-41). New York, Pageant.

KROETSCH, Robert (1989). "No Name is My Name". The Lovely Treachery of Words : Essays Selected and New. Toronto, Oxford U P, pp. 41-52.

KURATH, Gertrude (1968). Dance and Song Rituals of Six Nations Reserve, Ontario. Bulletin 220 Ottawa, National Museum of Canada.

LOTMAN, Yuri (1990). Universe of the Mind : A Semiotic Theory of Culture. Trans. Ann Shukman. Bloomington, Indiana U P.

LUSIGNAN, Serge (1988). "La Topique de la translatio siudii et les

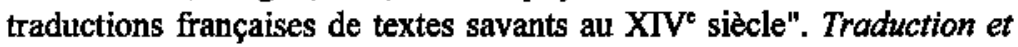
traducteurs au Moyen Age. Paris, Editions du CNRS. 
MARACLE, Lee (1988). I Am Woman. Vancouver, Write-on Press.

MOONEY, James [1896], 1965). The Ghost Dance Religion and the Sioux Outbreak of 1890 . 2nd ed. Chicago, U Chicago P.

MOSES, Daniel David (1992a). Almighty Voice and His Wife. Stratford, Williams-Wallace.

_(1997). Brébeuf's Ghost. Toronto, Playwrights Union of Canada. (1990). Coyote City. Stratford, Williams-Wallace.

MOSES, Daniel David and Terry GOLDIE (1992b). "Preface: Two Voices". An Anthology of Canadian Native Literature in English. Toronto, Oxford U P.

O'MEARA, John (1996). Delaware-English, English-Delaware Dictionary. Toronto, U Toronto P.

PARMENIUS, Stephen (1600). "Letter from Parmenius to Richard Hakluyt" (1583). Trans. Richard Hakluyt. In Hakluyt (1589), pp. 697-99; III, pp. 161-3.

PETRONE, Penny (ed.) (1983). Aboriginal Pre-Twentieth Century Canadian Literature Materials. Thunderbay, Faculty of Education, Lakehead University.

PIGGOTT, G.L and A. GRAFSTENN (1983). Ojibwa Lexicon. Ethnology Dossier No. 90. Ottawa, National Museum of Man.

QUINN, David B. and Neil M. CHESHIRE (1972). The Newfoundland of Stephen Parmenius. Toronto, U Toronto P.

RADIN, Paul (1969). The Trickster: A Study in American Indian Mythology. 2nd. ed. New York, Greenwood.

Report of the Royal Commission on Bilingualism and Biculturalism (19671972). I-VI. Ottawa, Queen's Printer. 
ROBINSON, Douglas (1991). The Translator's Turn. Baltimore, Johns Hopkins U P.

SCHECHNER, Richard (1988). Performance Theory. 2nd ed. rev. New York, Routledge.

SERRES, Michel (1974). Hermes III: La Traduction. Paris, Éditions de Minuit.

SPIVAK, Gayatri Chakravorty (1993). "The Politics of Translation". Outside in the Teaching Machine. New York, Routledge, pp. 179-200.

VALENTINE, Lisa Philips (1995). Making It Their Own : Severn Ojibwe Communicative Practices. Toronto, $\mathrm{U}$ Toronto $\mathrm{P}$.

VIZENOR, Gerald (1988). The Trickster of Liberty : Tribal Heirs to a Wild Baronage. Minneapolis, U Minnesota P.

WILSON, Edward F. (1874). The Ojebway Language : A Manual for Missionaries and Others Employed among the Ojebway Indians. Toronto, Rowsell and Hutchison for the Society for Promoting Christian Knowledge.

ABSTRACT : Writing Between Cultures - This essay examines the traffic in languages or systematic interferences, the tropes of translation whereby the network of the Canadian literary system is produced. It focuses on two moments in that process, one whereby Canadian literatures are produced as Europe's other by vertical translation of Canadian concepts into classical languages and an erasure of horizontal translation among Amerindian languages as manifest in the writing of colonization, especially in the work of Marie de l'Incarnation. The second is the contemporary period where the theatre of cultures of Amerindian playwrights, Daniel David Moses in particular, restages the trope of nontranslation to expose therein the rhetorical violence of imperialism and offers in its place a model of horizontal translation between Amerindian languages. Performance as repetition with a difference or rewriting is another mode of translation, characterized by a theory of language as event not as mimesis. 
RÉSUMÉ : Écrire entre les cultures - Cet essai examine le trafic des langues ou interférences systématiques, les tropes de la traduction par lesquels se constitue le réseau du système littéraire canadien. Deux moments sont ici considérés. Le premier, lorsque les littératures canadiennes se constituent comme l'Autre de l'Europe par la traduction verticale de concepts canadiens dans les langues classiques ainsi que par l'effacement des traductions horizontales entre les langues amérindiennes, ainsi que l'on peut l'observer dans les écrits de la colonisation et particulièrement dans ceux de Marie de l'Incarnation. Le second concerne la période contemporaine où le théâtre des cultures amérindiennes, celui de Daniel David Moses en particulier, remet en scène le trope de la nontraduction afin d'exposer la violence rhétorique de limpérialisme et offre comme option un modèle de traduction horizontal entre les langues amérindiennes. La performance comme répétition dans la différence où la ré-écriture s'offre comme un autre mode de traduction caractérisé par une théorie du langage en tant qu'événement et non mimesis.

Barbara Godard : 217, rue Major, Toronto, Ontario, M5S 2L4, tél. : (416) 929-5519. 